\title{
Evaluation of the Biological Effects of Lyophilized Hydrophilic Extract of Rhus coriaria on Myeloperoxidase (MPO) Activity, Wound Healing, and Microbial Infections of Skin Wound Tissues
}

\author{
Sami A. Gabr $(\mathbb{D})$ and Ahmad H. Alghadir $(\mathbb{D}$ \\ Rehabilitation Research Chair, College of Applied Medical Sciences, King Saud University, Riyadh, Saudi Arabia \\ Correspondence should be addressed to Sami A. Gabr; sgabr@ksu.edu.sa
}

Received 23 December 2018; Revised 3 June 2019; Accepted 2 July 2019; Published 14 July 2019

Academic Editor: Mohammed S. Ali-Shtayeh

Copyright (c) 2019 Sami A. Gabr and Ahmad H. Alghadir. This is an open access article distributed under the Creative Commons Attribution License, which permits unrestricted use, distribution, and reproduction in any medium, provided the original work is properly cited.

\begin{abstract}
Impaired wound healing was mainly associated with severe microbial infections which significantly affect diagnostic and therapeutic strategies. Thus, in this study, the potential wound healing activity, anti-inflammatory, and antimicrobial activity of an aqueous extract of Rhus coriaria extract (AERc) were evaluated by wound contraction, scar formation, period of epithelization, MPO enzyme activity, collagenase-2 (MMP-8), hydroxyproline (HPX), and collagen deposition as markers of wound healing at different days of postwound. Phytoconstituents, microbial activity, and fibrogenic markers were screened by HPLC, disc-diffusion, and colorimetric assays. The animals were treated with Rhus coriaria extract (AERc) concentrations at doses of $5 \mathrm{mg} \cdot \mathrm{kg}^{-1}$ and 10 mg.kg ${ }^{-1}$, respectively. On days 6 and 9, the AERc-treated animals at doses of $5 \mathrm{mg} \cdot \mathrm{mL}^{-1}$ and $10 \mathrm{mg} \cdot \mathrm{mL}^{-1}$ exhibited a significant reduction in the wound area, increased deposition of collagen, HPX, and reduction in MMP-8, and MPO enzyme activity when compared with controls. Scar formation and epithelization were completed in 10 days compared to controls. In addition, in wounds infected separately with Staph. aureus or P. aeruginosa, the AERc extract significantly improved wound contraction, deposition of collagen, and HPx and reduced MMP-8 and MPO concentrations, with complete epithelization of wounds in 10-13 days compared to the saline-treated group. Hydrolyzable tannins, gallic acid, quercetin, and myricetin were the most common active components of AERc. In vitro, the AERc and its components were effective against a set of microbes especially Staph. aureus, P. aeruginosa, and Staph. aureus (MRSA). In conclusion, the results showed that antimicrobial, anti-inflammatory, and antioxidant activity of Rhus coriaria extract suggested its importance as a target for formulation of novel drugs against many microbial infections with minimal side effects and could play a good potential role in accelerating wound healing activity via promoting myofibroblast activity, increase of hydroxyproline and collagen deposition, and regulation of MMP-8 and MPO enzyme activities.
\end{abstract}

\section{Introduction}

Wound healing is considered as one of the most complicated biological processes which is performed through a cascade of four overlapping phases: hemostasis, inflammatory, proliferative, and maturation. These stages result in the death of old tissues and regeneration of new ones. However, any defect or irregularity in this process may lead to severe microbial infections and impairment in wound healing, subsequently causing diagnostic and therapeutic problems $[1,2]$. In infected wounds, the concomitant killing of regenerating cells was reported resulting in the formation of unpleasant exudates, toxins, and finally poor or lack of healing process $[3,4]$. Up till now, drugs that could have efficient biological activities to promote and improve the natural process of wound healing with the human body, have not been introduced [5]. Consequently, to have a rapid healing process, we should prevent microbial infection and activate tissue repair processes [3].Thus, herbal medicines from natural sources have been shown to play an essential role in healthcare/promotion whereas about $80 \%$ of these plants have a globally ethnomedical use [6]. 
Among these herbal medicines is Rhus coriaria L. (Anacardiaceae), known as sumac, a wild edible-medicinal plant growing in tropical and temperate regions worldwide [7]. Sumac is one of the herbal plants traditionally used in the treatment of many diseases, including diabetes, cancer, and stroke [7-11]. Sumac was shown to have numerous health properties including antioxidant [12], antifibrogenic [13], antitumorigenic activities [14], and hypoglycaemic [15]. In addition, all parts of $R$. coriaria plants are known to possess nonmutagenic, fever reducing, DNA protective, antiseptic, antifungal, antibacterial, antioxidant, anti-ischemic, hypouricaemic, hypoglycaemic, and hepatoprotective properties, which support its traditional uses as wound healing agent particularly in infected wounds [11].

Myeloperoxidase (MPO) enzyme, is a haeme-containing protein secreted from Neutrophils as the first sign of inflammation or injury of cell and tissues [16-18]. In blood, MPO concentrations are currently measured as a marker of neutrophil initiation and degranulation [16-20]. Additionally, previous research studies showed that MPO concentrations are significantly lower in wound fluid (WF) of acute healing wounds compared to those present in tissues of pressure ulcers [21]. It is widely proposed that WF containing MPO before and after the healing process could have the potential to provide important biochemical information of wound healing and treatment against microbial infections [22, 23]. In monitoring the progression of wound healing, the MPO enzyme was shown to provide reliable diagnostic pieces of information about the overall status of a wound. In addition, wound exudates were used efficiently to follow up specified parameters which can help in diagnosis or in a particular wound therapy [23-26].

In this study, the wound healing activity and antiinflammatory and antimicrobial activity of Rhus coriaria extract (sumac) were evaluated by wound contraction, scar formation, period of epithelization, MPO enzyme activity, collagenase-2 (MMP-8), hydroxyproline (HPX), and collagen deposition as markers of wound healing at different days of postwound.

\section{Materials and Methods}

2.1. Preparation of Rhus coriaria Aqueous Extracts. Fruits of Rhus coriaria were purchased from the local spice store (Othaim Markets) in Riyadh, Saudi Arabia. The dried whole fruits well-triturated in a homegrinder (Mx Type A505, Moulinex, Ecully Cedex, France). The aqueous extract of Rhus coriaria, called AERc, was prepared by infusing $50 \mathrm{~g}$ of powdered plant material for 20 minutes using $300 \mathrm{~mL}$ of boiling water. The extract was then filtered, lyophilized to produce a good yield of $23.4 \%(w t=w t)$. Upon use, the extract was reconstituted into the required concentration (5 mg. $\mathrm{kg}^{-1}$ and $\left.10 \mathrm{mg} . \mathrm{kg}^{-1}\right)$ in sterile endotoxin-free water $[1,5]$.

\subsection{Phytoconstituents Screening of Rhus coriaria Fruits Aque-} ous Extracts. The phytoconstituents present in aqueous extract of Rhus coriaria extract (AERc) were determined by using previously reported standard screening tests [26].
2.3. Assessment of the Total Anthocyanins Contents of Aqueous Rhus coriaria Extract. In the appropriately diluted Rhus coriaria aqueous extracts, the total concentrations of anthocyanins present were measured at $520 \mathrm{~nm}$ by a UV-Vis spectrophotometer (Varian Cary 100 Scan, Palo Alto, CA, USA) according to the $\mathrm{pH}$ differential method [27]. The total estimated values of anthocyanins were expressed as $\mathrm{mg}$ of cyanidin 3-glucoside equivalents (CGE)/kg of extract.

2.4. Assessment of the Total Phenolic and Flavonoid Contents of Aqueous Rhus coriaria Extract. The total phenolic content was determined by adding $5 \mathrm{~mL}$ of Folin-Ciocalteu (FC) commercial reagent diluted with water $(1: 10 \mathrm{v} / \mathrm{v})$ and $4 \mathrm{~mL}$ of a $7.5 \%$ sodium carbonate solution as previously reported in the Folin-Ciocalteu (FC) colorimetric method [28]; then the mixture was stirred for $2 \mathrm{~h}$ at room temperature and kept away from strong light until a blue color appears. Finally, the total phenolic content was measured spectrophotometrically at absorbance of $765 \mathrm{~nm}$, and the results were expressed as $\mathrm{g}$ of gallic acid equivalents (GAE)/kg of extract.

Similarly, the amounts of flavonoids in plant extracts were estimated according to the Dowd method as adapted by Lamien-Meda et al. [29]. The produced flavonoids were expressed as mg of Quercetin Equivalents (QE) /100 mg of fractions from the calibrated curve.

2.5. Estimation of Active Constituents in Aqueous Rhus coriaria Extract. Hydrolysable tannins, gallic acid, quercetin, and myricetin derivatives as active constituents were estimated in aqueous Rhus coriaria fruits extracts (AERc) by using HPLC method [29-32]. HPLC analysis using a $4.6 \mathrm{~mm}$ x 150 mm ODS C18 column with UV detector was performed to detect the bioactive phenolic compounds present in 50 mg of AERc water extract at significant mobile phase of methanol-dH2O (40: $60 \%$ ) adjusted at flow rate $0.60 \mathrm{ml} / \mathrm{min}$ and separation time of $15 \mathrm{~min}$. The data were monitored using detector of $230 \mathrm{~nm}$ as previously reported [29-32]. These compounds were estimated in $23.4 \%$ (w/w) of the AERc product and were kept in the dark at $-20^{\circ} \mathrm{C}$ until studied $[11,31,33]$.

2.6. Antimicrobial Activity Test. Antimicrobial activities of AERc extract were evaluated against a set of microorganisms; gram positive Staphylococcus aureus (ATCC 12600), Staphylococcus aureus (MRSA), and streptococcus aureus. Gram negative Pseudomonas aeruginosa (ATCC 9721), Escherichia coli (ATCC 8677), Proteus vulgaris, and Shigella spp. (CIP 5451). In this study, to measure the antimicrobial activity of our AERc extract, the MRSA-strain was selected based upon the guidelines of the National Committee for Clinical Laboratory Standards [33]; the starin previously showed a resistance to methicillin (DMPPC) and oxacillin (MPIPC). Antimicrobial activity of AERc extract was estimated by previously reported modified diffusion test activity [34].

The colonies of the studied bacteria were picked directly from the plate and were suspended in $5 \mathrm{~mL}$ of sterile $0.85 \%$ saline. To have colony forming unites of $10^{8}(\mathrm{CFU}) / \mathrm{ml}$, the turbidity of the initial suspension was adjusted by comparing 
TABLE 1: Full elucidation of experimental design.

\begin{tabular}{|c|c|}
\hline Group & Description \\
\hline G1: & Saline non infected group; rats received topical application $(200 \mu \mathrm{L})$ of solutions containing saline $(\mathrm{NaCl}, 0.9 \%)$. \\
\hline G2: & Standard treatment group; non-infected rats received fibrinolysin (Fibrase SA ${ }^{\circledR}$ ) topically as once daily at a dose of $0.5 \mathrm{~g}$. \\
\hline G3: & $\begin{array}{l}\text { Non infected Rats treated with AERc extract at doses of } 5 \mathrm{mg} \cdot \mathrm{kg}-1 \text { for once a day for } 9 \text { consecutive days starting from the day } \\
\text { of wounding. }\end{array}$ \\
\hline G4: & $\begin{array}{l}\text { Non-infected Rats treated with AERc extract at doses of 10nmg.kg-1 for once a day for } 9 \text { consecutive days starting from the } \\
\text { day of wounding. }\end{array}$ \\
\hline G5: & $\begin{array}{l}\text { Saline infected group; infected rats with either Staphylococcus aureus (ATCC 25923) or Pseudomonas aeruginosa received } \\
\text { topical application }(200 \mu \mathrm{L}) \text { of solutions containing saline }(\mathrm{NaCl}, 0.9 \%) \text {. }\end{array}$ \\
\hline G6: & $\begin{array}{l}\text { Infected rats with either Staphylococcus aureus (ATCC 25923) or Pseudomonas aeruginosa received 1\% silver sulfadiazine } \\
\text { (Dermazine }{ }^{\circledR} \text { ) topically as standard treatment once daily }\end{array}$ \\
\hline G7: & $\begin{array}{l}\text { Infected rats with Staphylococcus aureus (ATCC 25923) treated with AERc extract at doses of } 5 \mathrm{mg} . \mathrm{kg}-1 \text { for once a day for } 9 \\
\text { consecutive days starting from the day of wounding }\end{array}$ \\
\hline G8: & $\begin{array}{l}\text { Infected rats with Staphylococcus aureus (ATCC 25923) treated with AERc extract at doses of } 10 \text { mg.kg-1 for once a day for } 9 \\
\text { consecutive days starting from the day of wounding }\end{array}$ \\
\hline G9: & $\begin{array}{l}\text { Infected rats with Pseudomonas aeruginosa received AERc extract at doses of } 5 \mathrm{mg} . \mathrm{kg}-1 \text { for once a day for } 9 \text { consecutive days } \\
\text { starting from the day of wounding }\end{array}$ \\
\hline G10: & $\begin{array}{l}\text { Infected rats with Pseudomonas aeruginosa received AERc extract at doses of } 10 \mathrm{mg} \cdot \mathrm{kg}-1 \text { for once a day for } 9 \text { consecutive days } \\
\text { starting from the day of wounding }\end{array}$ \\
\hline
\end{tabular}

with 0.5 McFarland's standard. All bacterial starins were grown in different petri dishes to exponential phase in Mueller-Hinton broth at $37^{\circ} \mathrm{C}$ for $18 \mathrm{~h}$ and compared with McFarland density [35]. The AERc extract at concentrations of $5 \mathrm{mg} \cdot \mathrm{kg}^{-1}$ and $10 \mathrm{mg} \cdot \mathrm{kg}^{-1}$ and blank and positive controls were added separately to each well $(4 \mathrm{~mm})$ of agar plate and allowed to diffuse at room temperature for 15-20 mim. The test was performed three times for each dose of AERc extract and positive control, respectively. In addition, chloramphenicol (1 mg.mL-1) and distillated water $(40 \mu \mathrm{L})$ were used as positive and blank controls respectively. Finally, after incubation for $24 \mathrm{hrs}$ at $37^{\circ} \mathrm{C}$, all plates were examined for growth inhibition zones and the diameter of each zone was measured. The average diameter in $\mathrm{mm}$ of the inhibition zone surrounding the wells containing the test solution was referred as the antimicrobial activity effects of AERc extract and positive control against microbial activity [1].

2.7. Animals. Fifty Wistar male rats of either sex weighing 180-250g were obtained from the experimental animal care center, college of applied medical sciences, King Saud Univ., Riyadh, Saudi Arabia. The animals were housed and subjected to normal feeding, drinking, and health care mechanism according to the guidelines of the breeding care unit at college of applied medical sciences. Animals had no history of surgery and infection, and other medical interventions were included in this study.

2.7.1. Excision Wound Model Assessments. The animals were anesthetized with ketamine hydrochloride $(50 \mathrm{mg} / \mathrm{kg}$, i.p., body weight) in combination with xylazine hydrochloride (10 $\mathrm{mg} / \mathrm{kg}$ ) of body weight [36] and shaved at the predetermined area, dorsum portion using depilatory cream (Reckitt Benckiser, Inc., UK) beforehand wounding. A circular wound of approximately $2 \mathrm{~cm}$ in diameter was performed on the anterior-dorsal side of each mouse by using a sterile surgical blade as described previously [37].

2.8. Experimental Design. Based upon wound infection, the animals were randomly classified into two groups: non infected group (20 rats) and infected group (30 rats). In infected group, the wounds of the rats were inoculated (10 $\mu \mathrm{L}$ ) separately with Staphylococcus aureus (ATCC 25923) and Pseudomonas aeruginosa (ATCC 9721) at $10^{8}$ Colony Forming Unit (CFU). Wound infection model was estimated to be successful if yellowish white pus was present on the wounds. During topical wound treatments, the rats of both groups were further subdivided into the following groups as shown in Table 1

2.9. Wound Contraction and Epithelialization Assessments. Wound contraction and epithelialization period were calculated as percentage reduction in wound area. The progressive changes in wound area were monitored by a camera (Sony Cyber Shot, Dscw80) on wounding day, followed by measurements on $3 \mathrm{rd}$, , 6th, and 9th day. Later on, the contraction in wound area was evaluated by using ImageJ program [37]. Following treatment periods, skin tissue samples from the heald sites were isolated from anesthetized animals and subjected for wound healing and histobiochemical analysis.

2.10. Assessment of Wound Healing and Epithelialization Rate. For each animal, the wound area was measured on days 3, 6, and 9 after surgery by tracing the wounds with the help of transparent sheet as previously reported [38]. The percent of the wound contraction was calculated from the data of the wound size measurements which was taken at the time of surgery and at the time of biopsy as previously reported [39], using the equation

$$
\left[\frac{(\mathrm{A} 0-\mathrm{At})}{\mathrm{A} 0}\right] \times 100=\% \text { of wound closure }
$$


where A0 is the original wound area and At is the area of wound at the time of biopsy.

Epithelialization period was calculated as previously reported [40], as the number of days required for falling off the dead tissue remnants of the wound without any residual raw wound.

2.11. Assessment of Hydroxyproline. Hydroxyproline was estimated from a dried wound tissues at $60^{\circ} \mathrm{C}$ as previously reported [41]; the tissues were hydrolyzed with adding $5 \mathrm{~mL}$ of $6 \mathrm{~N} \mathrm{HCl}$ for three hours at $130^{\circ} \mathrm{C}$. Neutral hydrolysates (pH7.0) were subjected to Chloramine-T oxidation for 20 min in room temperature. After $10 \mathrm{~min}, 0.4 \mathrm{M}$ perchloric acid was added as solution of stop reaction, termination of chloramine T oxidation. Finally for color development, $1 \mathrm{~mL}$ of Ehrlich's reagent was added to tubes, shook, and placed in water bath $\left(60^{\circ} \mathrm{C} / 20 \mathrm{~min}\right)$. Hydroxyproline concentration was measured in cooled solutions colorimetrically at $557 \mathrm{~nm}$ by using ultraviolet (Systronics-2203) spectrophotometer. Hydroxyproline and collagen concentrations were measured according to the following equations:

$$
\begin{aligned}
& \left\{\text { hydroxyproline concentration }(\mathrm{g} / \mathrm{ml})=\frac{(\mathrm{As}-\mathrm{Ab})}{(\text { Ast }-\mathrm{Ab})}\right. \\
& \quad \times \text { concentration of standard }(5 \mathrm{~g} / \mathrm{ml}) \\
& \quad \times \text { dilution factor; collagen concentration }(\mathrm{g} / \mathrm{ml}) \\
& =\text { hydroxyproline concentration } \times 7.46 \\
& \quad \times \text { dilution factor }\}
\end{aligned}
$$

see $[42]$.

2.12. Assessment of Myeloperoxidase (MPO). MPO activity was estimated in tissue samples as previously reported [43]. Briefly, $10 \mathrm{~mL}$ of wound tissue supernatant was mixed with $290 \mathrm{~mL}$ substrate solution, containing $100 \mathrm{mmol} / \mathrm{L}$ Guaiacol (Sigma-Aldrich) and $0.017 \%(\mathrm{w} / \mathrm{w}) \mathrm{H}_{2} \mathrm{O}_{2}$ in $50 \mathrm{mmol} / \mathrm{L}$ potassium phosphate buffer ( $\mathrm{pH}$ 7.0). For calibration, enzyme standards containing $0.16 \mathrm{U} / \mathrm{mL}$ up to $10.0 \mathrm{U} / \mathrm{mL} \mathrm{MPO}$ (Sigma-Aldrich) were prepared. The resultant tetraguaiacol compound was estimated as measure of MPO activity every $20 \mathrm{~s}$ for $15 \mathrm{~min}$ at $470 \mathrm{~nm}$. The change of optical density per minute was calculated five times from the initial rate. Finally, the increase in absorbance after $100 \mathrm{~s}$ was used for calculation of MPO activity. MPO activity was estimated in infected and noninfected wounds to determine the antioxidant and antiinflammatory activity of AERc extract [43].

2.13. Assessment of Collagenase-2 (MMP-8). Collagenase-2 (MMP-8) was estimated from the supernatant of excised wound tissues by enzyme immune assay ELISA technique as previously mentioned [44]. In ELISA plate, a total of 150 $\mu \mathrm{l}$ of assay diluents RD1-52 was added and followed by the addition of $50 \mu \mathrm{l}$ of standard or sample tissues to each well. The palate was gently tapped to ensure thorough mixing, covered, and incubated for $2 \mathrm{~h}$ at room temperature (18$25^{\circ} \mathrm{C}$ ). After incubation time, the plate was washed four times with washing buffer. To remove the excess washing buffer, the plate was inverted and blotted against clean paper towels and then a total of $200 \mu \mathrm{l}$ of MMP- 8 conjugate was added to all the wells. The plate was then securely covered with a plate sealer and incubated for $1 \mathrm{~h}$ at room temperature. Again, the plate was washed 4 times followed by the addition of $200 \mu \mathrm{l}$ of substrate solution to each well and incubated for $30 \mathrm{~min}$ at room temperature out of the light. After incubation period (30 $\mathrm{min}$ ), $50 \mu \mathrm{l}$ of stop solution was added in each well to stop the enzyme-substrate reaction. The optical density of the developed yellow color was determined within $30 \mathrm{~min}$, using a microplate reader set to $450 \mathrm{~nm}$ as the primary wavelength. The levels of MMP- 8 in the tissue samples were estimated using the standard curve and the concentrations were expressed as $\mathrm{ng} / \mathrm{ml}$.

2.14. Statistical Analysis. In this study, for the analysis of the data, a statistical software SPSS version 17 was used. The results obtained were expressed as Mean and standard deviation among groups; Kruskal-Wallis one-way ANOVA and and post-hoc (Tukey HSD) test were used to compare the mean values of the studied variables. Additionally, Spearman rank correlation analysis was performed to assess the relationship between various study parameters. The data obtained were deemed significant at $\mathrm{P}<0.05$.

\section{Results}

3.1. Phytoconstituents Screening. A total of $23.4 \% \mathrm{w} / \mathrm{w}$ of active phytoconstituents were estimated from Rhus coriaria fruits extracts (AERc). Alkaloids, flavonoids, glycosides, tannins, triterpenoids, glycosides, phenols, saponins, and anthraquinone were shown to be the most common phytoconstituents in AERc (Table 2). The aqueous extract of Rhus coriaria fruits was more concentrated in anthocyanins (98.3 $\pm 0.21 \mathrm{CGE} / \mathrm{kg})$, flavonoids $(78.6 \pm 0.81 \mathrm{QE} / \mathrm{g})$, and phenols $(4.5 \pm 1.2 \mathrm{GAE} / \mathrm{g})$. Hydrolyzable tannins $(38.1 \%)$, gallic acid $(21.8 \%)$, and quercetin (15.8\%) were the most active components present in higher amounts, followed by lowest amounts of myricetin (10.1\%) derivatives as active constituents present in AERc (Figure 2)

3.2. Antimicrobial Activity of Rhus coriaria Fruits Extracts. Table 3 shows the antibacterial activity of aqueous extracts of Rhus coriaria fruits against a set of bacterial strains; Staph. aureus, $P$. aeruginosa, strep. aureus, E. coli, $P$. vulgaris, and Shigella spp. The AERc at doses of $5 \mathrm{mg} \cdot \mathrm{mL}^{-1}$ and 10 $\mathrm{mg} \cdot \mathrm{mL}^{-1}$ showed the highest antibacterial activity against Staph. aureus, Staph. aureus (MRSA), Strep. aureus, and $P$. aeruginosa compared to that present against E. coli, $P$. vulgaris, and Shigella spp. In addition, hydrolyzable tannins, gallic acid, quercetin, and myricetin were the most common active components that showed higher activity against the studied bacteria, while quercetin and myricetin at dose of $5 \mathrm{mg} \cdot \mathrm{mL}^{-1}$ had no effect against E. coli, P. vulgaris, and Shigella spp., respectively. Chloramphenicol, a standard antibiotic, showed significant antibacterial activity against the test organisms. Due to the potential higher activities of 
TABLE 2: Phytoconstituents screening of aqueous Rhus coriaria fruits extracts (AERc mg/50mg).

\begin{tabular}{lc}
\hline Item & AERc mg/50mg \\
\hline Percentage yield & $23.4 \%$ \\
Phytochemical screening (+/-): & + \\
Alkaloids & + \\
Flavonoids & + \\
Tannins & + \\
Glycosides & + \\
Triterpenoids & + \\
phenols & + \\
Saponins & - \\
Quinone & + \\
Anthraquinone & \\
Phytochemical constituents $(M \pm S D)$ & $4.5 \pm 1.2$ \\
Total phenolics ${ }^{1}$ & $78.6 \pm 0.81$ \\
Total flavonoids ${ }^{2}$ & $98.3 \pm 0.21$ \\
Total Anthocyanins & \\
\hline
\end{tabular}

(+/-) presence or absence of phytoconstituents; phytochemical constituents represented as mean $\pm \mathrm{SD}(n=3) .{ }^{1}$ Expressed as mg of gallic acid equivalents (GAE)/g of the dry extract. ${ }^{2}$ Expressed as mg of quercetin equivalents $(\mathrm{QE}) / \mathrm{g}$ of the dry extract. ${ }^{3}$ Expressed as mg of cyanidin 3-glucoside equivalents (CGE)/kg.

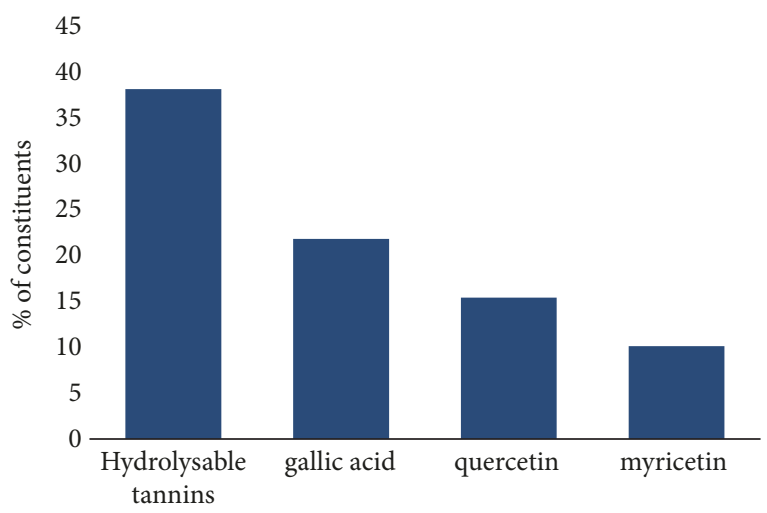

Active constituents of Rhus coriaria fruits extract

FIgURE 1: Screening of active Phytochemical contents present in aqueous extract of Rhus coriaria fruits.

the AERc at doses of $5 \mathrm{mg} \cdot \mathrm{mL}-1$ and $10 \mathrm{mg} \cdot \mathrm{mL}-1$ against Staph. aureus ATCC 12600, the antimicrobial activity against Staph. aureus MRSA was assessed. Results demonstrated that the AERc at doses of $5 \mathrm{mg} . \mathrm{mL}-1$ and $10 \mathrm{mg} . \mathrm{mL}-1$ induced an inhibition zone of 19.7 and $22.4 \mathrm{~mm}$ for strain MRSA, value similar to that presented by the standard strain. Also, hydrolyzable tannins, gallic acid, quercetin, and myricetin showed a considerable inhibition activity against the growth of strain MRSA (Table 3).

\subsection{Effect of AERc on Wound Closure and Epithelialization} Period. The wound healing activity of the aqueous extract prepared from Rhus coriaria fruits (AERc) was evaluated on mice in the excision wound models to confirm the potential healing and antimicrobial activity of the plant (Figure 1). In wounds treated with Rhus coriaria fruits extracts at doses of $5 \mathrm{mg} \cdot \mathrm{mL}-1$ and $10 \mathrm{mg} \cdot \mathrm{mL}-1$, the rates of wound closure were significantly increased from days $6^{\text {th }}$ to $15^{\text {th }}$ after wound excision compared to saline and standard treated rats, respectively (Figure 2).

In all groups, the area of the wound closure was measured on the days 3, 6 and 9 days after surgery. The progress of wound healing induced by the extract, reference drug, and saline-treated-groups in the excision of noninfected wounds are shown in Table 4.

The effect of AERc on the progression of wound closure, scar formation, and the period of epithelialization was estimated in noninfected wounds (Table 4). After application of AERc topically onto noninfected wounds, the area of wound reduced to $30 \%$; $55 \%$ of their original size $\left(2 \mathrm{~cm}^{2}\right)$ on day 3 , $57.5 \% ; 77.5 \%$ on day 6 and $83 \%$; 91.5 on day 9 ; and complete closure around day 10 following treatment with AERc at doses of $5 \mathrm{mg} \cdot \mathrm{mL}-1$ and $10 \mathrm{mg} \cdot \mathrm{mL}-1$, respectively.

In saline-treated animals, the area was reduced to $12.0 \%$ (day 3), $22 \% \mathrm{~cm}^{2}$ (day 6), and $40.0 \%$ (day 9). The wound closure in animals treated with reference drug, Fibrase, was $15 \%$ (day 3 ), 25\% (day 6), and 54\% (day 9) (Table 4). Treatment with AERc in noninfected wounds was able to reduce to 9 days the period of epithelialization when compared with the saline-treated group and Fibrase group, which were, respectively, 15.5 and 12.8 days.

Table 5 shows the changes in wound closure, scar formation, and the period of epithelialization in infected wounds treated with AERc. In wounds infected with gram-positive bacteria (Staph. aureus), the area of reduction in wounds was $30 \%$ and $40 \%$ of their original size $(2 \mathrm{~cm} 2)$ on day $3,40 \%$ and $52 . \%$ on day 6 , and $96 \%$ and $97 \%$ on day 9 , and complete closure on days 12 and 10 was reported following application of AEBv topically at doses of $5 \mathrm{mg} \cdot \mathrm{mL}-1$ and $10 \mathrm{mg} \cdot \mathrm{mL}-1$, respectively (Table 5 ).

In case of wounds infected with gram negative bacteria (P. aeruginosa), there was significant reduction in wounds to $25 \%$ and $30 \%$ of their original size $\left(2 \mathrm{~cm}^{2}\right)$ on day $3,40 \%$ and $52.5 \%$ on day 6 , and $56.5 \%$ and $62.5 \%$ on day 9 , and complete closure on days 13 and 12 was reported following application of AEBv topically at doses of $5 \mathrm{mg} \cdot \mathrm{mL}-1$ and 10 mg.mL-1, respectively (Table 4). On the other hand, in salinetreated animals, the area of wounds was reduced to $20 \%$ (day 3), 30\% (day 6), and 45\% (day 9). The wound closure in animals treated with reference drug, Dermazine ${ }^{\circledR}$, was $23.0 \%$ (day 3), 42\%, and 62.5\% (days 6 and 9) (Table 5). Treatment with AERc in infected wounds was able to reduce to around $10-13$ days the period of epithelialization when compared with the saline-treated group and Dermazine ${ }^{\circledR}$ group, which was, respectively, 19.5 and 16 days. In addition, complete scar formation occurred without any raw wound residues at days of complete epithelialization in noninfected wounds (9.5-10.8 days) and infected wounds (10-13 days) following AERC treatments at doses of $5 \mathrm{mg} \cdot \mathrm{mL}-1$ and $10 \mathrm{mg} \cdot \mathrm{mL}-1$, respectively. The mean scar area after complete healing was 98.5-99.8 $\mathrm{mm}^{2}$ for noninfected wounds and $94.7-99.8 \mathrm{~mm}^{2}$ for infected wounds, respectively (Tables 4 and 5). 


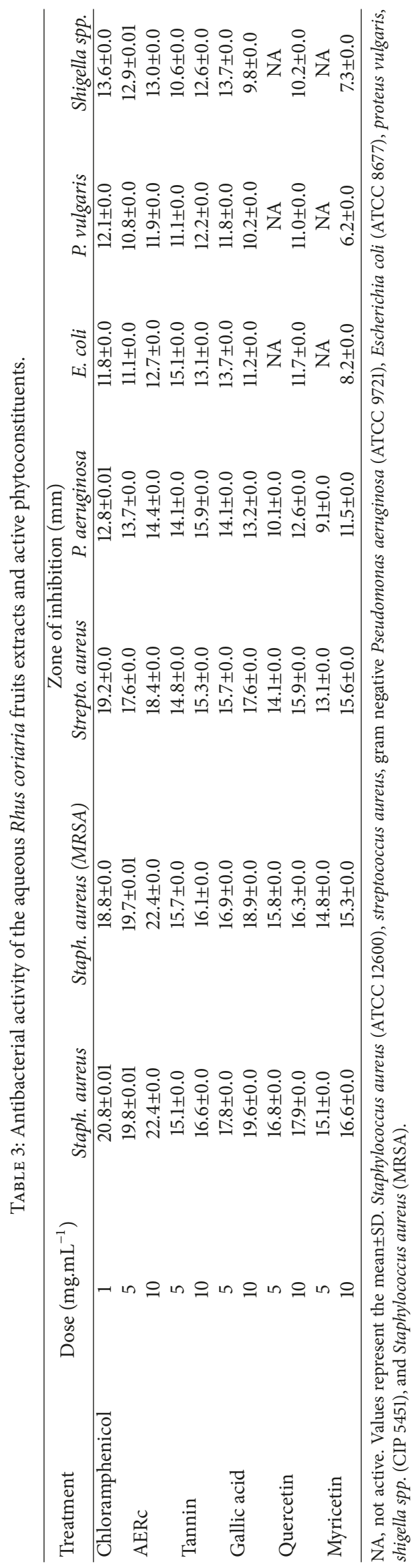


TABLE 4: Effect of aqueous extract of Rhus coriaria fruits on non-infected wounds.

\begin{tabular}{lccccc}
\hline \multirow{2}{*}{ Treatment } & \multicolumn{4}{c}{ Parameters of non-infected wounds } \\
& 3 & 6 & 9 & Scar area $\left(\mathrm{mm}^{2}\right)$ & Period of epithelization (Days) \\
\hline G1 & $1.76 \pm 0.16$ & $1.56 \pm 0.12$ & $1.2 \pm 0.09$ & $90.8 \pm 3.4$ & $15.5 \pm 0.5$ \\
G2 & $1.7 \pm 0.25$ & $1.5 \pm 0.10$ & $0.92 \pm 0.07^{\mathrm{a}}$ & $97.1 \pm 2.5^{\mathrm{b}}$ & $12.8 \pm 0.65^{\mathrm{a}}$ \\
AERc & & & & \\
G3 (5 mg.mL & & & & \\
G4 (10 mg.m) & $1.4 \pm 0.15$ & $0.85 \pm 0.06$ & $0.34 \pm 0.04^{\mathrm{b}, \mathrm{c}}$ & $98.5 \pm 1.3^{\mathrm{b}, \mathrm{c}}$ & $10.8 \pm 0.6^{\mathrm{b}, \mathrm{c}}$ \\
\hline
\end{tabular}

Values represent the mean $\pm \mathrm{SD},(\mathrm{n}=10)$. Statistical differences were determined by ANOVA followed Student Newman-Keuls test. G1: rats with non infected wounds treated topically with saline solution $(200 \mu \mathrm{L}$ of $\mathrm{NaCl}, 0.9 \%)$; G2: rats with non infected wounds treated with Fibrase ${ }^{\circledR}$ topically at dose of 0.5 g; G3: rats with non infected wounds treated topically with AERc at dose of $5 \mathrm{mg} \cdot \mathrm{mL}^{-1}$; G4: rats with non infected wounds treated topically with AERc at dose of 10 mg.mL-1. ${ }^{\text {a }} \mathrm{P}<0.001,{ }^{\mathrm{b}} \mathrm{P}<0.01$, as compared to respective saline treatment $(\mathrm{G} 1) .{ }^{\mathrm{c}} \mathrm{P}<0.001$ as compared to Fibrase-treated animals (G2). AERc: aqueous extract of Rhus Coriaria extract.

TABLE 5: Effect of aqueous extract of Rhus coriaria fruits on infected wounds.

\begin{tabular}{|c|c|c|c|c|c|}
\hline \multirow{3}{*}{ Treatment } & \multicolumn{5}{|c|}{ Wounds infected with Gram positive (Staph. aureus) } \\
\hline & \multicolumn{3}{|c|}{ Wound area $\left(\mathrm{cm}^{2}\right)$ on day } & \multirow{2}{*}{ Scar area $\left(\mathrm{mm}^{2}\right)$} & \multirow{2}{*}{ Period of epithelization (Days) } \\
\hline & 3 & 6 & 9 & & \\
\hline G5 & $1.6 \pm 0.06$ & $1.4 \pm 0.06$ & $1.1 \pm 0.06$ & $91.8 \pm 1.4$ & $19.5 \pm 0.6$ \\
\hline G6 & $1.54 \pm 0.04$ & $1.16 \pm 0.03$ & $0.75 \pm 0.05^{\mathrm{a}}$ & $97.3 \pm 3.5^{b}$ & $16.0 \pm 0.0^{\mathrm{a}}$ \\
\hline \multicolumn{6}{|l|}{ AERc } \\
\hline G7 $\left(5 \mathrm{mg} \cdot \mathrm{mL}^{-1}\right)$ & $1.4 \pm 0.12$ & $0.58 \pm 0.08$ & $0.08 \pm 0.03^{b, c}$ & $98.7 \pm 1.9^{b, c}$ & $12.0 \pm 0.0^{\mathrm{b}, \mathrm{c}}$ \\
\hline G8 (10 mg.mL $\left.\mathrm{m}^{-1}\right)$ & $1.2 \pm 0.11$ & $0.35 \pm 0.02$ & $0.06 \pm 0.01^{\mathrm{a}, \mathrm{c}}$ & $99.8 \pm 0.4^{\mathrm{a}, \mathrm{c}}$ & $10.8 \pm 0.1^{\mathrm{a}, \mathrm{c}}$ \\
\hline
\end{tabular}

Wounds infected with Gram Negative (P. aeruginosa)

\begin{tabular}{|c|c|c|c|c|c|}
\hline \multirow[t]{2}{*}{ Treatment } & \multicolumn{3}{|c|}{ Wound area $\left(\mathrm{cm}^{2}\right)$ on day } & \multirow[t]{2}{*}{ Scar area $\left(\mathrm{mm}^{2}\right)$} & \multirow{2}{*}{ Period of epithelization (Days) } \\
\hline & 3 & 6 & 9 & & \\
\hline \multicolumn{6}{|l|}{ AERc } \\
\hline G9 (5 mg.mL $\left.L^{-1}\right)$ & $1.5 \pm 0.19$ & $1.2 \pm 0.11$ & $0.87 \pm 0.21^{\mathrm{b}, \mathrm{c}}$ & $94.7 \pm 2.9^{\mathrm{b}, \mathrm{c}}$ & $13.0 \pm 0.0^{\mathrm{b}, \mathrm{c}}$ \\
\hline $\mathrm{G} 10\left(10 \mathrm{mg} \cdot \mathrm{mL}^{-1}\right)$ & $1.4 \pm 0.18$ & $0.95 \pm 0.12$ & $0.75 \pm 0.10^{\mathrm{a}, \mathrm{c}}$ & $99.1 \pm 0.4^{\mathrm{a}, \mathrm{c}}$ & $12.0 \pm 0.0^{\mathrm{a}, \mathrm{c}}$ \\
\hline
\end{tabular}

Values represent the mean $\pm \mathrm{SD}(\mathrm{n}=10)$. Statistical differences were determined by ANOVA followed Student-Newman-Keuls test. G5: infected rats with either Staphylococcus aureus (ATCC 25923) or Pseudomonas aeruginosa received topical application (200 $\mu \mathrm{L}$ ) of solutions containing saline ( $\mathrm{NaCl}, 0.9 \%)$; G6: infected rats with either Staphylococcus aureus (ATCC 25923) or Pseudomonas aeruginosa received 1\% silver sulfadiazine (Dermazine ${ }^{\circledR}$ ) topically as standard treatment once daily; G7: infected rats with Staphylococcus aureus (ATCC 25923) treated with AERc extract at doses of $5 \mathrm{mg} . \mathrm{kg}-1$ for once a day for 9 consecutive days; G8: infected rats with Staphylococcus aureus (ATCC 25923) treated with AERc extract at doses of $10 \mathrm{mg}$.kg-1 for once a day for 9 consecutive days; G9: infected rats with Pseudomonas aeruginosa received AERc extract at doses of $5 \mathrm{mg} . \mathrm{kg}-1$ for once a day for 9 consecutive days; G10: infected rats with Pseudomonas aeruginosa received AERc extract at doses of $10 \mathrm{mg} . \mathrm{kg}-1$ for once a day for 9 consecutive days. ${ }^{\mathrm{a}} \mathrm{P}<0.001,{ }^{\mathrm{b}} \mathrm{P}<0.01$ as compared to respective saline treatment. ${ }^{c} \mathrm{P}<0.001$ as compared to Dermazine-treated animals.

3.4. Effect of AERc on Myeloperoxidase (MPO) Activity in Wound Tissues. MPO enzyme activity was determined as a potential marker for the diagnosis of wound infection and healing process in skin wounded tissues infected separately with gram-positive and gram-negative bacteria. In this study, significantly higher MPO activity was detected in infected skin wounds (P. aeruginosa or Staph. aureus) when compared with noninfected wounds based on the oxidation of guaiacol using commercial MPO as standard (Figures 3(a) and 3(b)). After application of AERc topically at doses of $5 \mathrm{mg} . \mathrm{mL}-1$ and $10 \mathrm{mg} \cdot \mathrm{mL}-1$ onto infected and noninfected wounds, the levels of MPO activity decreased significantly at 9, 12, 15, 18, 21 days after surgery in all groups (Figures $3(\mathrm{a})$ and $3(\mathrm{~b})$ ).

The decrease in MPO activity was negatively correlated $(\mathrm{P}=0.001)$ with wound closer, scar formation, and complete epithelialization following treatments with AERc at the recommended doses (Table 6). The reduction in MPO activity greatly supports the antimicrobial and wound healing activities of Rhus coriaria fruits (AERc) against infection of skin wound tissues with gram-positive and gram-negative bacteria.

3.5. Effect of AERc on Fibrogenesis Markers. The levels of HPX and collagen were significantly $(P<0.001)$ higher in AERc, Dermazine, and fibrase treated rats than they were in saline-treated rats (control). Moreover, it was observed that the effects of AERc and standard controls (Dermazine and fibrase) were dose-dependent (Table 6). Compared to the normal control rats, both infected and noninfected skin wounds showed a significant increase $(P<0.001)$ in the levels of HPX and collagen as the fibrogenesis markers in their wounds (Table 6). In infected and noninfected skin wounds, a significant increase in the levels of HPX and collagen was 

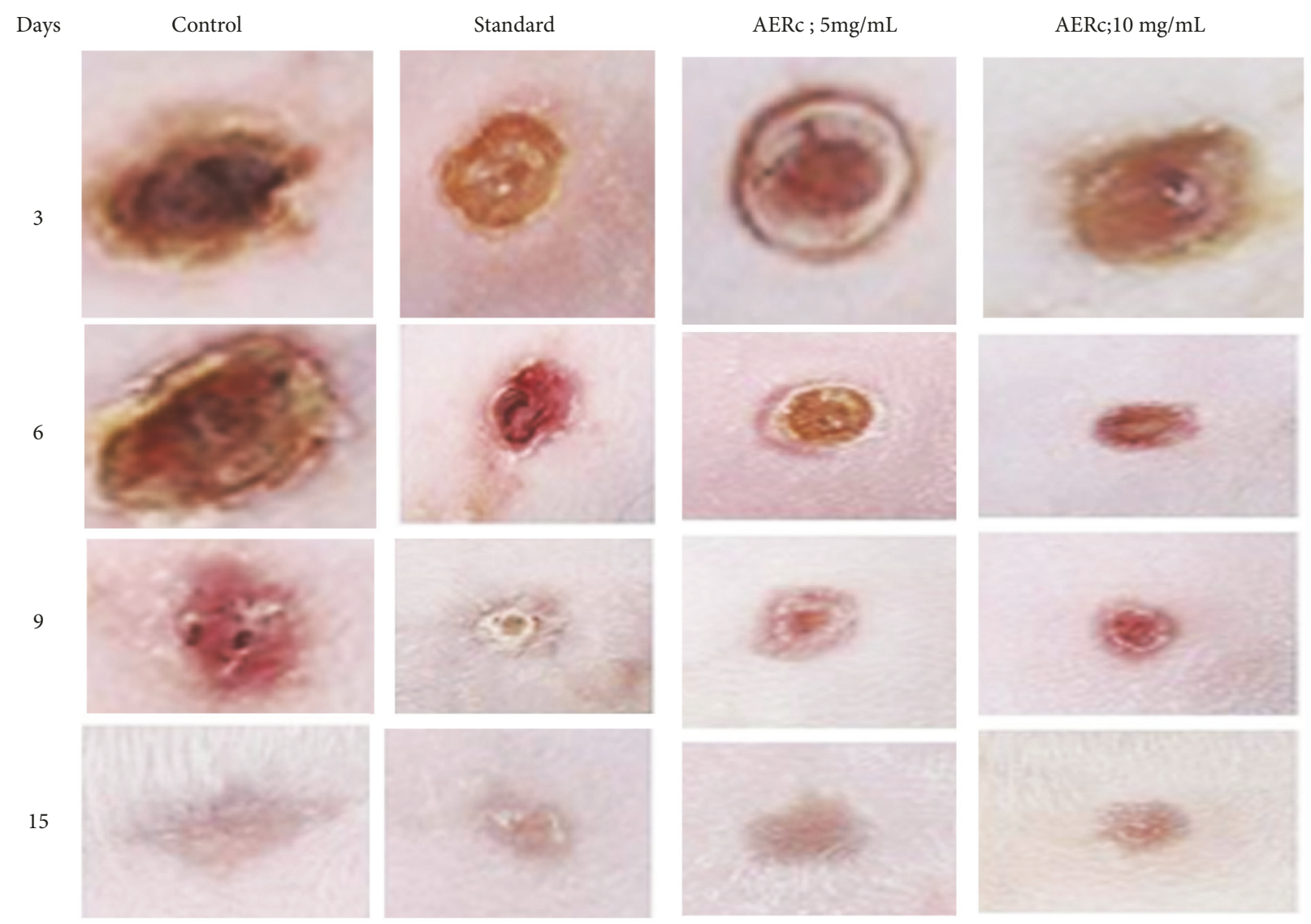

FIGURE 2: Photographs represent the percentage of wound closer rates on different postexcision days $\left(3^{\text {th }}--15^{\text {th }}\right)$.

TABLE 6: Effect of aqueous extract of Rhus coriaria fruits on collagenase-2 (MMP-8), hydroxyproline (HPX), and collagen contents in infected and non-infected excision wounds.

\begin{tabular}{|c|c|c|c|c|c|c|}
\hline \multirow{3}{*}{ Treatment } & \multicolumn{6}{|c|}{ Wounds } \\
\hline & \multicolumn{3}{|c|}{ Non-infected } & \multicolumn{3}{|c|}{ Infected } \\
\hline & MMP-8 & Collagen & HPX & MMP-8 & Collagen & HPX \\
\hline Saline & $48.9 \pm 8.5$ & $5.4 \pm 0.47$ & $115.4 \pm 3.4$ & $75.1 \pm 12.5$ & $3.5 \pm 0.53$ & $85.4 \pm 2.9$ \\
\hline Fibrase $^{\circledR}$ & $45.6 \pm 5.6^{\mathrm{a}}$ & $5.4 \pm 0.51$ & $121 \pm 6.4^{\mathrm{a}}$ & $71.3 \pm 6.5^{\mathrm{a}}$ & $3.6 \pm 0.35^{\mathrm{a}}$ & $89.1 \pm 3.1^{\mathrm{c}}$ \\
\hline Dermazine $^{\circledR}$ & $41.3 \pm 4.7^{\mathrm{b}}$ & $5.1 \pm 0.43^{\mathrm{a}}$ & $118.7 \pm 7.1^{\mathrm{a}}$ & $63.9 \pm 7.4^{\mathrm{b}}$ & $6.1 \pm 0.58^{b}$ & $135 \pm 5.4^{c}$ \\
\hline \multicolumn{7}{|l|}{ AERc } \\
\hline $5 \mathrm{mg} \cdot \mathrm{mL}^{-1}$ & $31.8 \pm 2.8^{c}$ & $11.6 \pm 0.31^{c}$ & $181.4 \pm 5.7^{\mathrm{c}}$ & $58.9 \pm 4.9^{c}$ & $10.2 \pm 0.72^{c}$ & $169.8 \pm 2.1^{\mathrm{c}}$ \\
\hline $10 \mathrm{mg} \cdot \mathrm{mL}^{-1}$ & $21.3 \pm 1.2^{c}$ & $19.6 \pm 0.27^{\mathrm{c}}$ & $215.8 \pm 9.1^{\mathrm{c}}$ & $44 \pm 6.1^{\mathrm{c}}$ & $15.7 \pm 0.35^{\mathrm{c}}$ & $269 \pm 2.6^{c}$ \\
\hline
\end{tabular}

Values are mean $\pm \mathrm{SD}$ of 10 rats in each group. ${ }^{\mathrm{a}} P<0.05,{ }^{\mathrm{b}} P<0.01$, and ${ }^{\mathrm{c}} P<0.001$ compared to respective control groups (Fibrase ${ }^{\circledR}$ and Dermazine ${ }^{\circledR}$ ) and standard. Statistical analysis was done by one-way analysis of variance followed by Tukey-Kramer Multiple Comparisons Test.

observed at days $6,9,12,15,18$, and 21 after treatment with AERc at doses of 5 mg.mL-1 and 10 mg.mL-1 as shown in Figures 3(c), 3(d), 4(c), and 4(d).

MMP-8 as a fibrogenic potential marker for measuring active wound healing was also estimated in tissue samples of noninfected and infected skin wounds (Table 6). In groups treated with AERc at doses of $5 \mathrm{mg} \cdot \mathrm{mL}-1$ and $10 \mathrm{mg} \cdot \mathrm{mL}-1$, the levels of MMP-8 activity greatly reduced in comparison with standard and saline-treated groups $(P<0.001)$. The decrease in the levels of MMP- 8 starts at days 6 up to 21 after treatment with AERc recommended doses and it showed to be significantly associated with the activity of AERc extract towards the acceleration of wound healing process in both infected and noninfected skin wounds as shown in Figures 4(a) and 4(b).

The expression rates of HPX, collagen deposition, and MMP-8 activity in skin wounds following treatment with AERc at doses of $5 \mathrm{mg} \cdot \mathrm{mL}^{-1}$ and $10 \mathrm{mg} \cdot \mathrm{mL}^{-1}$ showed significant correlation with wound healing parameters (Table 7). The rate of the wound closure, scar formation, and complete epithelialization correlated positively $(P<0.001)$ with HPX, collagen deposition, and negatively $(P<0.001)$ with MMP-8 


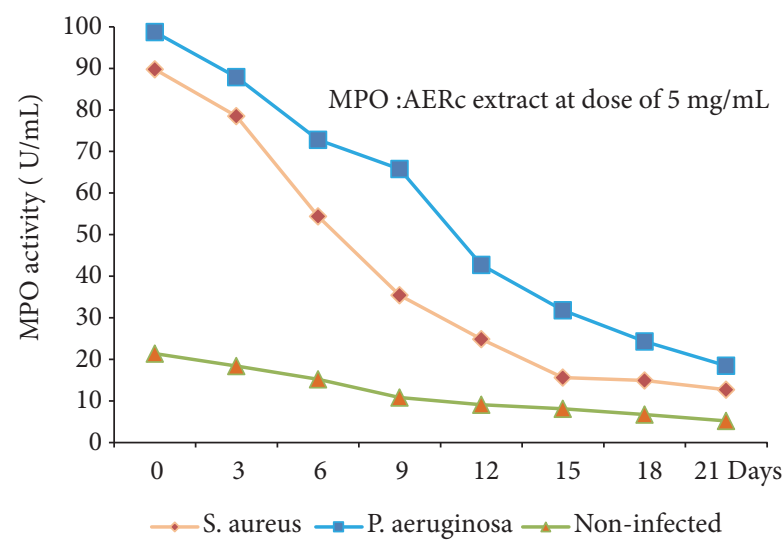

(a)

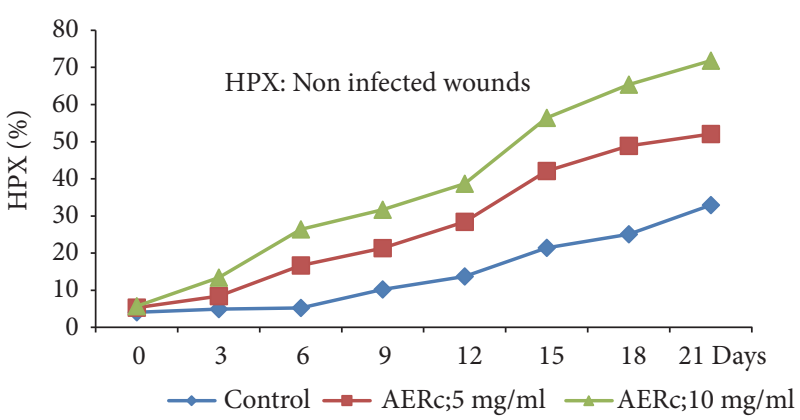

(c)

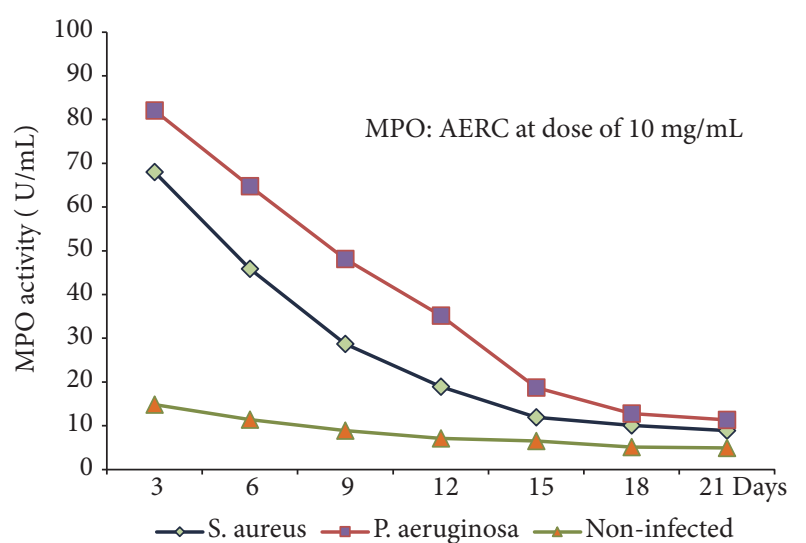

(b)

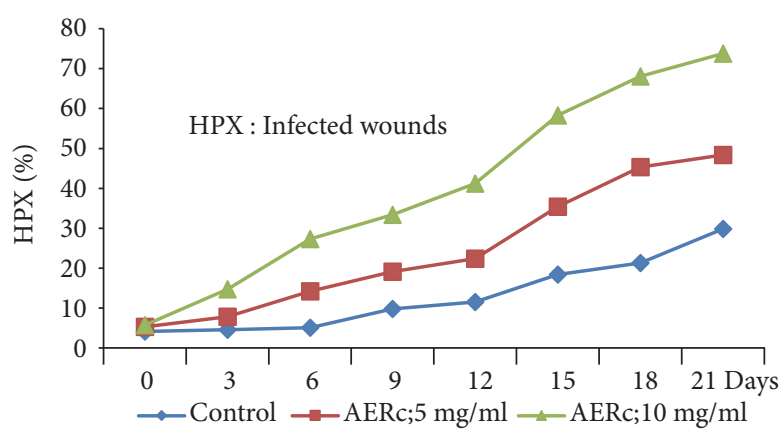

(d)

FIGURE 3: Effect of aqueous extract of Rhus coriaria fruits on myeloperoxidase (MPO) activity at a dose of $5 \mathrm{mg} \cdot \mathrm{mL}^{-1}$ of AERc (a) and at adose of $10 \mathrm{mg} \cdot \mathrm{mL}^{-1}$ of AERc (b) and hydroxyproline (HPX) in noninfected (c) and infected wounds (d) treated at 3, 6, 9, 15, and 21 postoperative days. In wounds infected with gram positive $(S$. aureus) and gram negative ( $P$. aeruginosa), there was significant decrease ( $\mathrm{p}=0.001)$ in the level of MPO activity and increase $(\mathrm{p}<0.05)$ in the levels of HPX at days $15 \mathrm{th}, 18^{\text {th }}$, and $21^{\text {st }}$ following treatment with AERc at doses of 5 $\mathrm{mg} \cdot \mathrm{mL}^{-1}, 10 \mathrm{mg} \cdot \mathrm{mL}^{-1}$, and compared with control treatments, respectively.

TABLE 7: Correlation between parameters of wound closer and collagenase-2 (MMP-8), Myeloperoxidase (MPO) activity, hydroxyproline (HPX), and collagen contents in infected and non-infected wounds treated with aqueous extract of Rhus coriaria fruits.

\begin{tabular}{lccc}
\hline Item & wound closer $(\%)$ & Scar formation $(\mathrm{mm} 2)$ & Epithelialization period (Days) \\
\hline Hydroxyproline $(\mu \mathrm{g} / \mathrm{g}$ of tissues) & $0.14^{\mathrm{b}}$ & $0.42^{\mathrm{b}}$ & $0.28^{\mathrm{b}}$ \\
collagen $(\mathrm{g} / \mathrm{mL})$ & $0.78^{\mathrm{b}}$ & $0.58^{\mathrm{b}}$ & $0.85^{\mathrm{b}}$ \\
MPO activity $(\mathrm{U} / \mathrm{mL})$ & $-0.45^{\mathrm{b}}$ & $-041^{\mathrm{b}}$ & $-0.47^{\mathrm{b}}$ \\
MMP-8 $(\mathrm{ng} / \mathrm{ml})$ & $-0.23^{\mathrm{b}}$ & $-0.65^{\mathrm{b}}$ & $-0.54^{\mathrm{b}}$ \\
\hline
\end{tabular}

Data presented as coefficient $(R) ;{ }^{\text {a }}$ significance at $<0.01{ }^{\text {b }}$ significance at $<0.001$.

activity following treatment with the recommended doses of AERc extract.

\section{Discussion}

Topical application of an aqueous extract of Rhus coriaria fruits (AERc) on infected and noninfected skin wounds of rats has shown the efficacy of the extract (AERc) in facilitating wound healing process at doses of $5 \mathrm{mg} \cdot \mathrm{mL}-1$ and 10 mg.mL-1, respectively. Additionally, wound healing promotion activity of AERc extract has been evaluated based on our screening analysis of its active phytoconstituents. The results showed that the aqueous extract (AERc) contains sufficient amounts of alkaloids, flavonoids, glycosides, tannins, triterpenoids, glycosides, phenols, saponins, and anthraquinone whereas anthocyanins and flavonoids were estimated in higher amounts in AERc extract followed by a considerable amount of phenols. The most active constituents present in the extract were hydrolyzable tannins, gallic acid, quercetin, and myricetin derivatives as measured by HPLC.

The presence of these active constituents was shown to be responsible for numerous health properties of Rhus coriaria fruits in treating many diseases as antidiabetes, anticancer, and antistroke [7-11]. Also, sumac was used traditionally in treating many physiological and cellular disorders as an antioxidant [12], antifibrogenic [13], antitumorigenic activities [14] and hypoglycaemic [15], DNA, and hepatoprotective properties [11]. So, due to the potential biological activities 


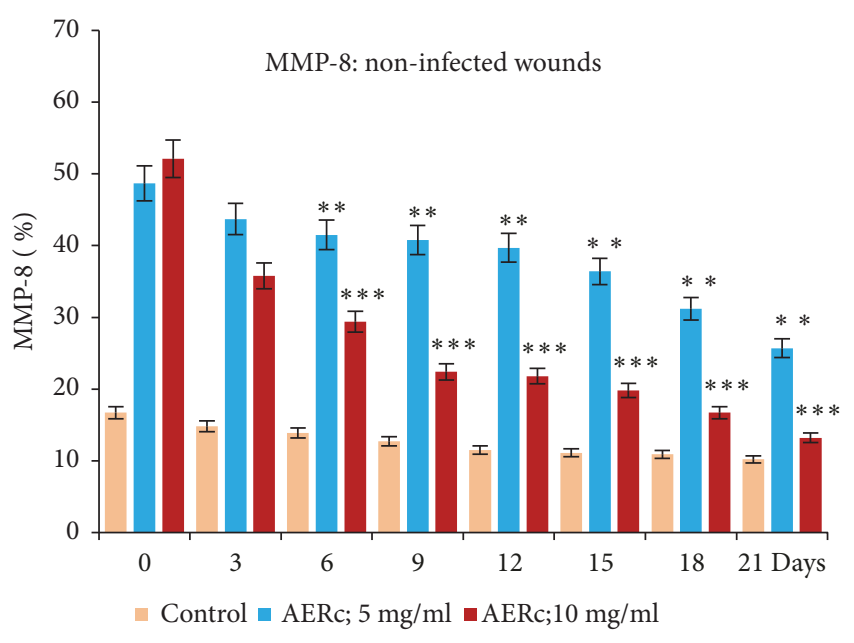

(a)

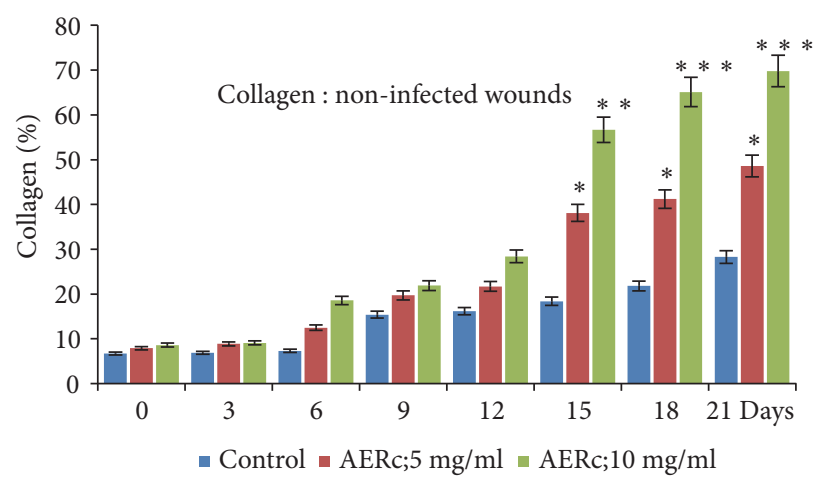

(c)

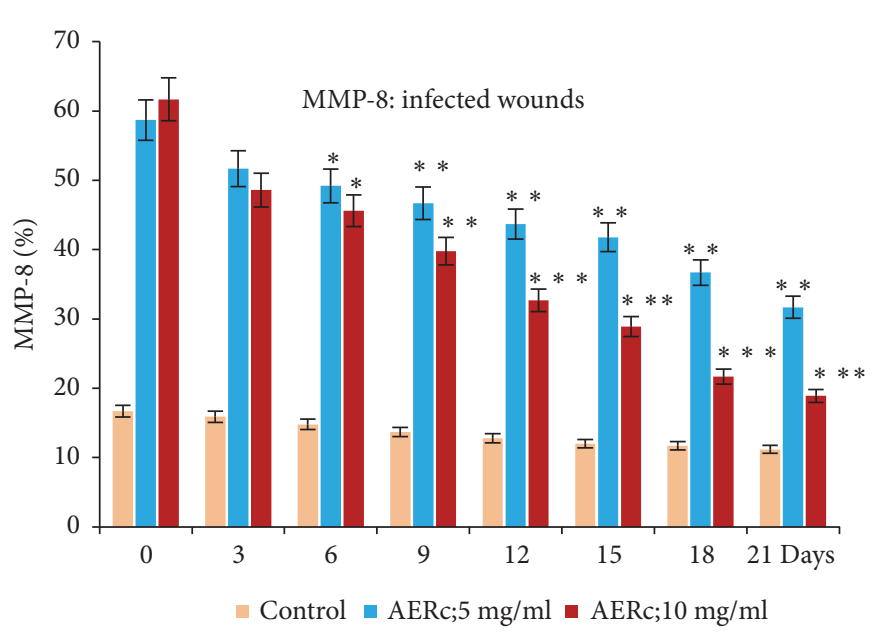

(b)

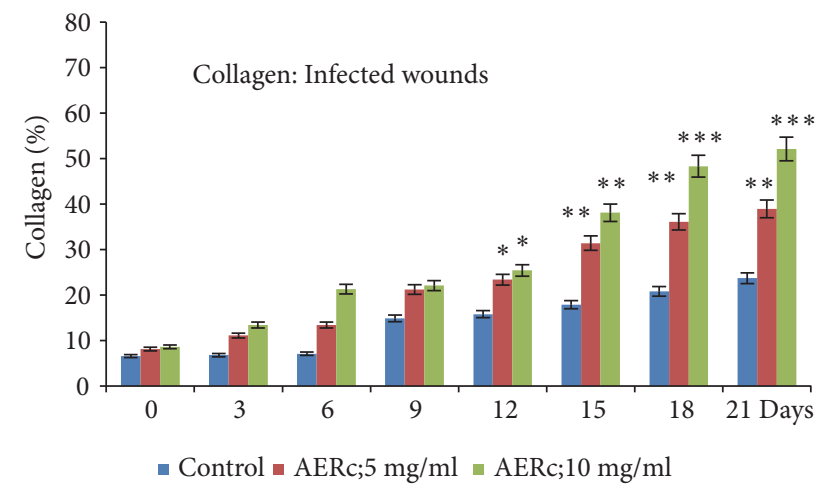

(d)

Figure 4: Mean values and standard errors of the percentage of MMP-8 (a) in noninfected, (b) infected wounds, and collagen in noninfected (c), and infected wounds (d). Wounds are infected separately with $10 \mu \mathrm{L}$ of S. aureus (ATCC 25923) and P. aeruginosa at 108 Colony Forming Unit (CFU). The data showed significant depletion in the activity of MMP-8 and increase in the level of collagen deposition in wounds of control and treated animals at $3,6,9,15$, and 21 postoperative days.

previously mentioned for Rhus coriaria fruits extracts, it can be suggested that this plant may have greater efficiency to promote wound healing and contribute in skin regeneration of infected and noninfected wounds.

In this study, the topical application of Rhus coriaria fruits extracts (AERc) at doses of $5 \mathrm{mg} \cdot \mathrm{mL}-1$ and $10 \mathrm{mg} \cdot \mathrm{mL}-$ 1 enhances cutaneous wound healing, which appeared completed in 10 days for noninfected skin wounds and around 1013 days for infected wounds according to the type of microbes and used dose of Rhus coriaria fruits extracts.

The histochemical findings showed that wound healing, scar formation, and the epithelialization rates, as well as tissue regeneration, were significantly correlated with greater expression of hydroxyproline, deposition of collagen fibers, and lower in the activities of both MMP-8 and MPO in skin wounds treated with the extract than in saline-treated wounds. The changes in fibrogenic markers for improving the healing process were mediated by myofibroblasts described firstly in healing skin wounds. It was proposed that myofibroblasts were responsible for the phenomenon of wound contraction $[45,46]$.
In granulated wound tissues, fibroblasts are activated to become myofibroblasts via acquiring $\alpha$-SM-actin expression. During the wound healing process, the activated myofibroblastic cells synthesize and deposit the surrounding extracellular matrix (ECM) components such as collagen and hydroxyproline, control the activity of MMP-8 and MPO, and eventually replace the provisional matrix. Additionally, it was reported that during healing, scar formation involves a progressive remodeling of the granulation tissue via expression of proteolytic enzymes, essentially matrix metalloproteinases (MMPs) particularly our MMP-8 enzyme one of these enzymes which play a major role with their inhibitors (tissue inhibitor of metalloproteinases [TIMPs]) in wound healing [47]. Also, it was reported that during healing of wounds, the deposited collagen fibers are changed from collagen type III, the major component of the granulation tissue to collagen type I which is the main structural component of the dermis, followed by elastin, which contributes to the final stage of skin epithelialization and elasticity. In addition, successive stages of synthesis, degradation, and orientation of collagen fibrils were involved in the scar remodeling process. During 
scar formation, collagen is deposited and randomly oriented to fibronectin fibers oriented in such manner depending on the nature and direction of the tensional forces applied to the scar [48-50]. At the final of healing, the cell number vascular cells and myofibroblasts are dramatically reduced by apoptosis [51]. So, the increase in wound contraction in AERc-treated rats might be a result of the enhanced activity of fibroblasts.

In this study, the increase in the activity of MMP- 8 and MPO was the first response to inflammation which starts immediately after wounding process, acting as a defense mechanism of the tissue, able to provide resistance to the microbial contaminations [52]. The release of MPO in tissues and blood circulation result from inflammatory processes $[53,54]$. Thus it considered now as a marker of neutrophil activation and degranulation $[19,55]$.

Gutiérrez-Fernández et al. [20] reported that matrix metalloproteinases (MMPs) have been implicated in numerous tissue-remodeling processes, especially collagenase-2 (MMP8 ). They found that mice deficient in collagenase-2 (MMP8) are more susceptible to develop skin cancer and delay in wound healing. The data of this study proved that the presence or expression of MMP-8 participates in wound repair by contributing to the resolution of inflammation stage.

In our study, the reduction in the activity of MMP-8 and MPO appeared at days 6-9 after surgery. This may be related to the progression of the proliferation and maturation phases of wound healing following treatment with AERc. So, the improved healing process might be due to the antiinflammatory activity of AERc extract whereas the wound healing process significantly delayed with long durations in the inflammatory phase [20]. Also, it was shown that the anti-inflammatory activity of the extract is essential for better wound healing in shorter periods [56]. Therefore, as previously reported the activity of our AERc extract was significantly related to its anti-inflammatory effects $[57,58]$. Also, the healing activity of sumac was shown to play a role in decreasing MPO enzyme activity [5]. These data provide evidence that Rhus coriaria extract accelerates cutaneous wound healing through decreasing MPO activity and oxidative damage in both infected and noninfected skin wounds. Previously, it was reported that Sumac leaves are good sources of phenolic acids and several flavonoids used frequently against many diseases as anti-inflammatory, antioxidant, antibacterial, fungicide, antiviral, and candidicide $[59,60]$.

A delay in the wound healing process was mainly associated with microbial attacks for wounds exposed to external unfavorable environments which may compromise the repair process. In skin wounds, Staph. aureus and P. aeruginosa are the most common pathogens responsible for infection $[61,62]$. Topical application of the extract AERc and standard drugs are more effective as a microbicide and increasing wound healing rate in a shorter time compared to control saline-treated rats. This is may be due to its greater availability at the infected wound site, compromise inflammation, and lesions produced due to microbial infections. In control rats, the slow rate of wound contraction is controlled by the presence of microorganisms which secrete metabolites, inhibiting wound contraction, and subsequently impair healing.

In infected wounds, even the period of epithelialization is greater compared with noninfected animals treated with AERc at doses of $5 \mathrm{mg} \cdot \mathrm{mL}^{-1}$ and $10 \mathrm{mg} \cdot \mathrm{mL}^{-1}$; there was a better wound healing if compared to animals treated with saline. The data was supported by previous research work which confirmed the extract of Sumac (Rhus coriaria) is used in traditional medicine as a medicinal herb for its antimicrobial and wound healing activity $[5,7]$

Also, to confirm the potential role of AERc sumac extract as antimicrobial in the healing process, in vitro analysis of the antimicrobial effect of AERc was performed against a set of gram-positive and gram-negative microorganisms. The data showed that AERc has a significant potential inhibitory effect against Staph. aureus, $P$. aeruginosa, Strep. aureus, E. coli, P. vulgaris, and Shigella spp.

In addition, hydrolyzable tannins, gallic acid, quercetin, and myricetin were the most common active components that showed higher activity against the studied bacteria, except for the fact that quercetin and myricetin had no effect against E. coli, P. vulgaris, and Shigella spp. at lower dose (5 mg.mL-1). In our previously reported studies, whole Rhus coriaria fruits extract and their active constituents showed higher antioxidant and antimicrobial activity against bacteria and fungi [63-65] Furthermore, our study showed that AERc was effective against a methicillin-resistant strain of Staph. aureus (MRSA). It was reported that MRSA are multiresistant and difficult for treatment due to the fact that up till now there are no satisfactory antimicrobial drugs [1, 33]. Therefore, regarding our present result, extract from $A E R c$ seem to have a potential efficiency to combat the problem of MRSA.

In conclusion, the results showed that antimicrobial, anti-inflammatory, and antioxidant activity of Rhus coriaria extract suggested its importance as a target for formulation of novel drugs against many microbial infections with minimal side effects and could play a good potential role in accelerating wound healing activity via promoting myofibroblast activity, increase of hydroxyproline and collagen deposition, and regulation of MMP- 8 and MPO enzyme activities.

\section{Data Availability}

All data generated or analyzed during this study are presented in the article. Please contact the corresponding author for access to data presented in this study.

\section{Ethical Approval}

The experiment and the procedures were approved by the Ethics Committee of the Experimental Animal Care Society, Rehabilitation Research Chair (RRC), College of Applied Medical Sciences, King Saud Univ., Riyadh, Saudi Arabia.

\section{Conflicts of Interest}

The authors declare that they have no conflicts of interest. This project was funded by the Deanship of Scientific 
Research, King Saud University through Vice Deanship of Scientific Research Chairs. The funding body played no role in the study design, manuscript writing, or decision to submit the manuscript for publication.

\section{Authors' Contributions}

Research idea, design, and practical work were proposed by Sami A. Gabr. Data collection and analysis were executed by Sami A. Gabr. Reformatting, drafting, and preparing of the revised manuscript were done by Sami A. Gabr and Ahmad H. Alghadir. Finally, manuscript preparation and submission were done by Sami A. Gabr.

\section{Acknowledgments}

The authors are grateful to the Deanship of Scientific Research, King Saud University for funding through Vice Deanship of Scientific Research Chairs.

\section{References}

[1] I. K. R. Agra, L. L. S. Pires, P. S. M. Carvalho, E. A. Silva-Filho, S. Smaniotto, and E. Barreto, "Evaluation of wound healing and antimicrobial properties of aqueous extract from Bowdichia virgilioides stem barks in mice," Anais da Academia Brasileira de Ciências, vol. 85, no. 3, pp. 945-954, 2013.

[2] B. S. Reddy, R. K. K. Reddy, V. G. M. Naidu et al., "Evaluation of antimicrobial, antioxidant and wound-healing potentials of Holoptelea integrifolia," Journal of Ethnopharmacology, vol. 115, no. 2, pp. 249-256, 2008.

[3] D. Schiffer, G. Tegl, R. Vielnascher et al., "Myeloperoxidaseresponsive materials for infection detection based on immobilized aminomethoxyphenol," Biotechnology and Bioengineering, vol. 113, no. 12, pp. 2553-2560, 2016.

[4] A. Hasmann, E. Wehrschuetz-Sigl, A. Marold et al., "Analysis of myeloperoxidase activity in wound fluids as a marker of infection," Annals of Clinical Biochemistry, vol. 50, no. 3, pp. 245-254, 2013.

[5] N. M. Mehrabani, M. Kamalinejad, Z. Khodaii, J. Kamali, S. Hashemi, and M. Dehghan, "Wound healing effect of aqueous extract of rhus coriaria in rat," Aristotle University Medical Journal, vol. 6, no. 1, p. 5159, 2017.

[6] D. S. Fabricant and N. R. Farnsworth, "The value of plants used in traditional medicine for drug discovery," Environmental Health Perspectives, vol. 109, no. 1, pp. 69-75, 2001.

[7] S. Rayne and G. Mazza, "Biological activities of extracts from sumac (Rhus spp.): a review," Plant Foods for Human Nutrition, vol. 62, no. 4, pp. 165-175, 2007.

[8] D. B. Ambikar, U. N. Harle, R. A. Khandare, V. V. Bore, and N. S. Vyawahare, "Neuroprotective effect of hydroalcoholic extract of dried fruits of trapa bispinosa roxb on lipofuscinogenesis and fluorescence product in brain of d-galactose induced ageing accelerated mice," Indian Journal of Experimental Biology, vol. 48, no. 4, pp. 378-382, 2010.

[9] H. Zargham and R. Zargham, "Tannin extracted from Sumac inhibits vascular smooth muscle cell migration," McGill Journal of Medicine, vol. 11, no. 2, pp. 119-123, 2008.

[10] M. Özcan, "Antioxidant activities of rosemary, sage, and sumac extracts and their combinations on stability of natural peanut oil," Journal of Medicinal Food, vol. 6, no. 3, pp. 267-270, 2003.
[11] I. M. Abu-Reidah, M. S. Ali-Shtayeh, R. M. Jamous, D. ArráezRomán, and A. Segura-Carretero, "HPLC-DAD-ESI-MS/MS screening of bioactive components from Rhus coriaria L. (Sumac) fruits," Food Chemistry, vol. 166, pp. 179-191, 2015.

[12] S. H. Lee, "The chalcone butein from Rhus verniciflua shows antifibrogenic activity," Planta Medica, vol. 69, no. 11, pp. 990994, 2003.

[13] R. Kossah, C. Nsabimana, H. Zhang, and W. Chen, "Evaluation of antimicrobial and antioxidant activities of Syrian Sumac fruit extract," Journal of Natural Products, vol. 6, pp. 96-102, 2013.

[14] A. Chakraborty, F. Ferk, T. Simić et al., "DNA-protective effects of sumach (Rhus coriaria L.), a common spice: results of human and animal studies," Mutation Research, vol. 661, no. 1-2, pp. 1017, 2009.

[15] T. Anwer, M. Sharma, G. Khan et al., "Rhus coriaria ameliorates insulin resistance in non-insulin-dependent diabetes mellitus (NIDDM) rats," Acta Poloniae Pharmaceutica. Drug Research, vol. 70, no. 5, pp. 861-867, 2013.

[16] S. J. Klebanoff, "Myeloperoxidase," Proceedings of the Association of American Physicians, vol. 111, pp. 383-389, 1999.

[17] O. Soehnlein, "An elegant defense: how neutrophils shape the immune response," Trends in Immunology, vol. 30, no. 11, pp. 511-512, 2009.

[18] J. A. Smith, "Neutrophils, host defense, and inflammation: a double-edged sword," Journal of Leukocyte Biology, vol. 56, no. 6, pp. 672-686, 1994.

[19] M. Brennan and S. L. Hazen, "Emerging role of myeloperoxidase and oxidant stress markers in cardiovascular risk assessment," Current Opinion in Lipidology, vol. 14, no. 4, pp. 353-359, 2003.

[20] C. Wu, J. Chen, W. Wu et al., "Myeloperoxidase serves as a marker of oxidative stress during single haemodialysis session using two different biocompatible dialysis membranes," Nephrology Dialysis Transplantation, vol. 20, no. 6, pp. 11341139, 2005.

[21] T. A. Dechert, A. E. Ducale, S. I. Ward, and D. R. Yager, "Hyaluronan in human acute and chronic dermal wounds," Wound Repair and Regeneration, vol. 14, no. 3, pp. 252-258, 2006.

[22] N. J. Trengove, S. R. Langton, and M. C. Stacey, "Biochemical analysis of wound fluid from nonhealing and healing chronic leg ulcers," Wound Repair and Regeneration, vol. 4, no. 2, pp. 234-239, 1996.

[23] D. R. Yager, R. A. Kulina, and L. A. Gilman, "Wound fluids: a window into the wound environment?" The International Journal of Lower Extremity Wounds, vol. 6, pp. 262-672, 2007.

[24] R. Mani, "Science of measurements in wound healing," Wound Repair and Regeneration, vol. 7, no. 5, pp. 330-334, 1999.

[25] R. F. Diegelmann and M. C. Evans, "Wound healing: an overview of acute, fibrotic and delayed healing," Frontiers in Bioscience, vol. 9, pp. 283-289, 2004.

[26] K. R. Khandelwal, Practical Pharmacognosy Techniques and Experiments, Nirali Prakashan, Pune, India, 2nd edition, 2005.

[27] P. Rapisarda, F. Fanella, and E. Maccarone, "Reliability of analytical methods for determining anthocyanins in blood orange juices," Journal of Agricultural and Food Chemistry, vol. 48, no. 6, pp. 2249-2252, 2000.

[28] V. L. Singleton, R. Orthofer, and R. M. Lamuela-Raventós, "Analysis of total phenols and other oxidation substrates and antioxidants by means of folin-ciocalteu reagent," Methods in Enzymology, vol. 299, pp. 152-178, 1999. 
[29] A. Lamien-Meda, C. Lamien, M. Compaoré et al., "Polyphenol content and antioxidant activity of fourteen wild edible fruits from Burkina Faso," Molecules, vol. 13, no. 3, pp. 581-594, 2008.

[30] M. Kosar, B. Bozan, F. Temelli, and K. Baser, "Antioxidant activity and phenolic composition of sumac (Rhus coriaria L.) extracts," Food Chemistry, vol. 103, no. 3, pp. 952-959, 2007.

[31] L. Regazzoni, E. Arlandini, D. Garzon, N. A. Santagati, G. Beretta, and R. Maffei Facino, "A rapid profiling of gallotannins and flavonoids of the aqueous extract of Rhus coriaria L. by flow injection analysis with high-resolution mass spectrometry assisted with database searching," Journal of Pharmaceutical and Biomedical Analysis, vol. 72, pp. 202-207, 2013.

[32] M. Waksmundzka-Hajnos, A. Oniszczuk, K. Szewczyk, and D. Wianowska, "Effect of sample-preparation methods on the HPLC quantitation of some phenolic acids in plant materials," Acta Chromatographica, no. 19, pp. 227-237, 2007.

[33] National Committee for Clinical Laboratory Standards, Methods for Dilution Antimicrobial Susceptibility Tests for Bacteria That Grow Aerobically, Approved Standard. NCCLS document M2-A8. 940, National Committee for Clinical Laboratory, Wayne, PA, USA, 2nd edition, 2003.

[34] H. Joung, D.-Y. Kwon, J.-G. Choi et al., "Antibacterial and synergistic effects of Smallanthus sonchifolius leaf extracts against methicillin-resistant Staphylococcus aureus under light intensity," Journal of Natural Medicines, vol. 64, no. 2, pp. 212215, 2010.

[35] P. R. Murray, E. J. Baron, M. A. Pfaller, F. C. Tenover, and R. H. Yolken, Manual of Clinical Microbiology, American Society for Microbiology, Washington, Wash, USA, 6th edition, 1995.

[36] S. O. Udegbunam, R. I. Udegbunam, C. C. Muogbo, M. U. Anyanwu, and C. O. Nwaehujor, "Wound healing and antibacterial properties of methanolic extract of Pupalia lappacea Juss in rats," BMC Complementary and Alternative Medicine, vol. 14, article 157, 2014.

[37] P. K. Mukherjee, R. Verpoorte, and B. Suresh, "Evaluation of in-vivo wound healing activity of Hypericum patulum (Family: Hypericaceae) leaf extract on different wound model in rats," Journal of Ethnopharmacology, vol. 70, no. 3, pp. 315-321, 2000.

[38] S. Nicoli, C. Padula, V. Aversa et al., "Characterization of rabbit ear skin as a skin model for in vitro transdermal permeation experiments: histology, lipid composition and permeability," Skin Pharmacology and Physiology, vol. 21, no. 4, pp. 218-226, 2008.

[39] F. Sadaf, R. Saleem, M. Ahmed, S. I. Ahmad, and Navaid-ulZafar, "Healing potential of cream containing extract of Sphaeranthus indicus on dermal wounds in Guinea pigs," Journal of Ethnopharmacology, vol. 107, no. 2, pp. 161-163, 2006.

[40] J. S. Boateng, K. H. Matthews, H. N. E. Stevens, and G. M. Eccleston, "Wound healing dressings and drug delivery systems: a review," Journal of Pharmaceutical Sciences, vol. 97, no. 8, pp. 2892-2923, 2008.

[41] B. K. Manjunatha, S. M. Vidya, K. V. Rashmi, K. L. Mankani, H. J. Shilpa, and S. D. J. Singh, "Evaluation of wound-healing potency of Vernonia arborea Hk," Indian Journal of Pharmacology, vol. 37, no. 4, pp. 223-226, 2005.

[42] I. Bergman and R. Loxley, "Two improved and simplified methods for the spectrophotometric determination of hydroxyproline," Analytical Chemistry, vol. 35, no. 12, pp. 1961-1965, 1963.

[43] X. Su, X. Liu, S. Wang et al., "Wound-healing promoting effect of total tannins from Entada phaseoloides (L.) Merr. in rats," Burns, vol. 43, no. 4, pp. 830-838, 2017.
[44] R. K. Desser, S. Himmelhoch, W. H. Evans, M. Januska, M. Mage, and E. Shelton, "Guinea pig heterophil and eosinophil peroxidase," Archives of Biochemistry and Biophysics, vol. 148, no. 2, pp. 452-465, 1972.

[45] D. J. Victor, S. Subramanian, P. P. Gnana, and S. P. Kolagani, "Assessment of matrix metalloproteinases-8 and -9 in gingival crevicular fluid of smokers and non-smokers with chronic periodontitis using ELISA," Journal of International Oral Health, vol. 6, no. 6, pp. 67-71, 2014.

[46] A. Desmoulière, I. A. Darby, and G. Gabbiani, "Normal and pathologic soft tissue remodeling: role of the myofibroblast, with special emphasis on liver and kidney fibrosis," Laboratory Investigation, vol. 83, no. 12, pp. 1689-1707, 2003.

[47] V. Moulin, F. A. Auger, D. Garrel, and L. Germain, "Role of wound healing myofibroblasts on re-epithelialization of human skin," Burns, vol. 26, no. 1, pp. 3-12, 2000.

[48] R. Visse and H. Nagase, "Matrix metalloproteinases and tissue inhibitors of metalloproteinases: structure, function, and biochemistry," Circulation Research, vol. 92, no. 8, pp. 827-839, 2003.

[49] C. A. Balbino, L. M. Pereira, and R. Curi, "Mecanismos envolvidos na cicatrização: uma revisão," Brazilian Journal of Pharmaceutical Sciences, vol. 41, no. 1, pp. 27-52, 2005.

[50] A. Oryan and A. H. Shoushtari, "Histology and ultrastructure of the developing superficial digital flexor tendon in rabbits," Anatomia, Histologia, Embryologia: Journal of Veterinary Medicine Series C, vol. 37, no. 2, pp. 134-140, 2008.

[51] P. D. Verhaegen, H. J. Schouten, W. Tigchelaar-Gutter et al., "Adaptation of the dermal collagen structure of human skin and scar tissue in response to stretch: an experimental study," Wound Repair and Regeneration, vol. 20, no. 5, pp. 658-666, 2012.

[52] A. Desmoulière, M. Redard, I. Darby, and G. Gabbiani, "Apoptosis mediates the decrease in cellularity during the transition between granulation tissue and scar," The American Journal of Pathology, vol. 146, no. 1, pp. 56-66, 1995.

[53] T. Kondo, “Timing of skin wounds," Legal Medicine, vol. 9, no. 2, pp. 109-114, 2007.

[54] D. W. Laight, B. Woodward, and J. F. Waterfall, "Assessment of myeloperoxidase activity in renal tissue after ischemia/reperfusion," European Journal of Pharmacology, vol. 292, pp. 81-88, 1994.

[55] T. Schneider and A. C. Issekutz, "Quantitation of eosinophil and neutrophil infiltration into rat lung by specific assays for eosinophil peroxidase and myeloperoxidase. Application in a Brown Norway rat model of allergic pulmonary inflammation," Journal of Immunological Methods, vol. 198, no. 1, pp. 1-14, 1996.

[56] A. Gutiérrez-Fernández, M. Inada, and M. Balbín, "Increased inflammation delays wound healing in mice deficient in collagenase-2 (MMP-8)," The FASEB Journal, vol. 21, no. 10, pp. 2580-2591, 2007.

[57] N. Shimizu, T. Watanabe, T. Arakawa, Y. Fujiwara, K. Higuchi, and T. Kuroki, "Pentoxifylline accelerates gastric ulcer healing in rats: roles of tumor necrosis factor alpha and neutrophils during the early phase of ulcer healing," Digestion, vol. 61, no. 3, pp. 157-164, 2000.

[58] J. P. Silva, R. S. Rodarte, A. S. Cal heiros et al., "Antinociceptive activity of aqueous extract of Bowdichia virgilioides in mice," Journal of Medicinal Food, vol. 13, pp. 348-351, 2010.

[59] S. M. Thomazzi, C. B. Silva, D. C. R. Silveira et al., "Antinociceptive and anti-inflammatory activities of Bowdichia virgilioides (sucupira)," Journal of Ethnopharmacology, vol. 127, no. 2, pp. 451-456, 2010. 
[60] S. M. Mavlyanov, S. Y. Islambekov, A. I. Ismailov, D. N. Dalimov, and N. G. Abdulladzhanova, "Vegetable tanning agents," Chemistry of Natural Compounds, vol. 37, no. 1, pp. 1-24, 2001.

[61] A. Zalacain, S. A. Ordoudi, I. Blázquez et al., "Screening method for the detection of artificial colours in saffron using derivative UV-Vis spectrometry after precipitation of crocetin," Food Additives \& Contaminants: Part A, vol. 22, no. 7, pp. 607615, 2005.

[62] D. S. Arora and G. J. Kaur, "Antibacterial activity of some Indian medicinal plants," Journal of Natural Medicines, vol. 61, no. 3, pp. 313-317, 2007.

[63] F. V. Romeo, G. Ballistreri, S. Fabroni et al., "Chemical characterization of different sumac and pomegranate extracts effective against botrytis cinerea rots," Molecules, vol. 20, no. 7, pp. 1194111958, 2015.

[64] S. A. Gabr, M. M. El-Metwally, and A. H. Al-Ghadir, "Antioxidant and antibacterial active constituents of Rhus coriaria," Biotechnology, vol. 13, no. 2, pp. 37-45, 2014.

[65] S. A. Gabr and A. H. Alghadir, "Phytochemical analysis and in vitro antifungal activities of bioactive fractions from leaves of Rhus coriaria (SUMAC)," Journal of Pure and Applied Microbiology, vol. 9, no. 1, pp. 559-565, 2015. 


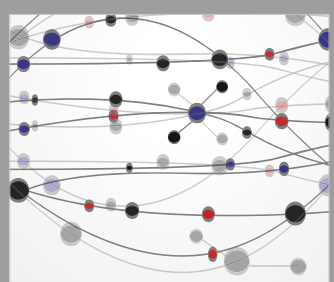

The Scientific World Journal
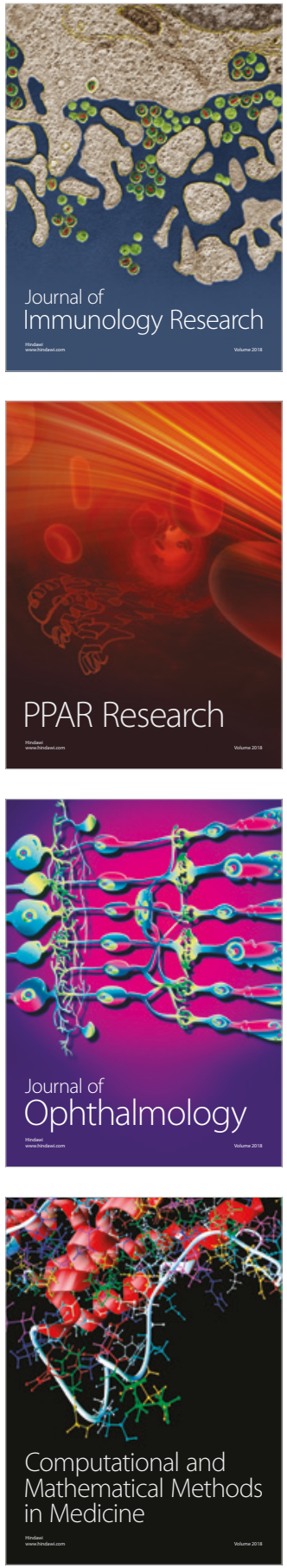

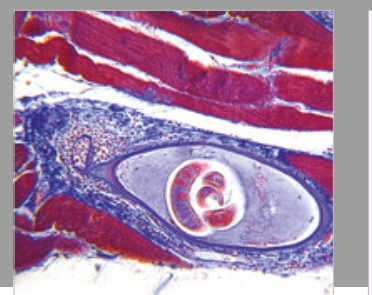

Gastroenterology Research and Practice

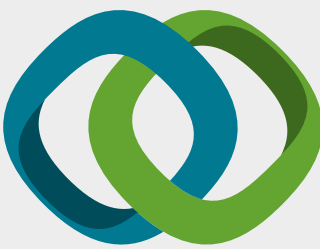

\section{Hindawi}

Submit your manuscripts at

www.hindawi.com
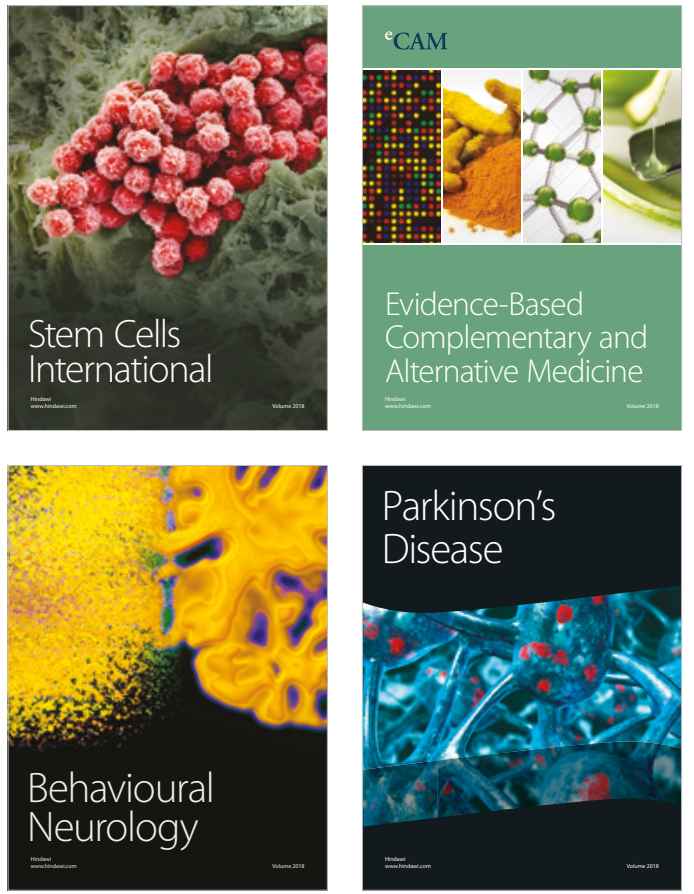

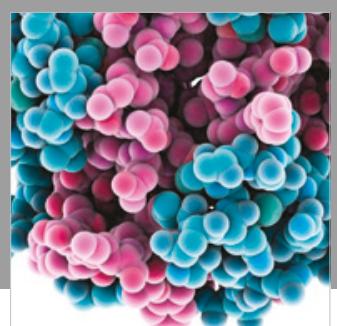

ournal of

Diabetes Research

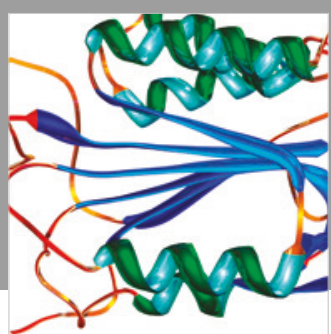

Disease Markers
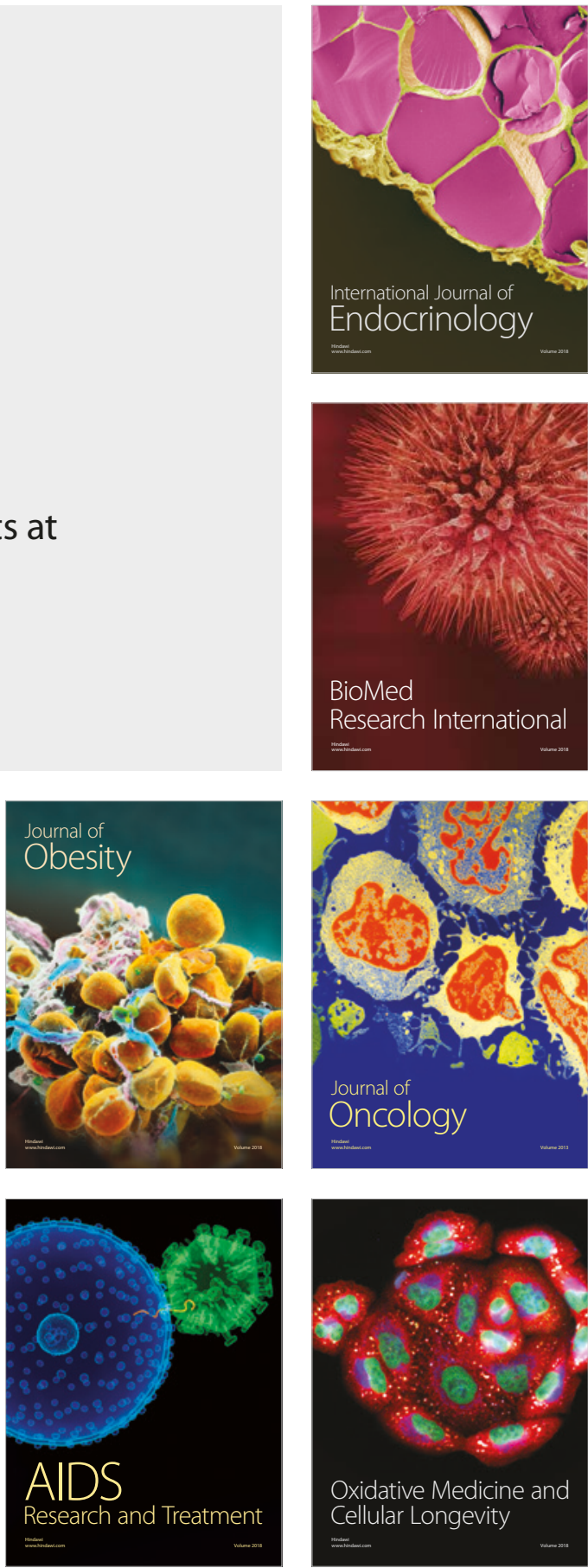